\title{
Improving Managerial Performance through Participation Role of Budget Preparation: a Theoretical and Empirical Overview
}

\author{
M. Taufiq Noor Rokhman \\ Faculty of Economics and Business, Wisnuwardhana University of Malang. Indonesia
}

\begin{abstract}
Both profit and nonprofit entity could gain the benefit from planning and control that is provided by the budget. In preparing the budget, it is good to differenciate the needs with the availability of budget, therefore, it will be executed properly with participative budgeting system. Many accounting management studies pay attention on the issue of participation budgeting in relation to managerial performance and produce opposition empirical results. The difference in the results of empirical studies occurs because the relationship of budget participation and managerial performance depend on situational factors, or better known as a Contingency Variable.
\end{abstract}

Keywords: managerial performance and budget preparation

\section{Introduction}

To achieve the goals of the company, there is the need for a strong and competent management in their field. Management is the party entrusted by the owner of the company in managing the company's investment in both outward and inward. According to Terry (1972) in the management principles, management is a typical process that consists of actions of planning, organizing, and controlling that are performed to determine and achieve the goals that have been determined through the use of resources.Management is expected to perform its functions in accordance with the objectives and targets to be set by the company. Therefore, we need a tool for management in some forms of formal planning of all activities of the company in a given period of time that is expressed qualitatively. The form of so-called budget planning which is not only a financial plan for a company, but also as a means of control, coordination, evaluation, and motivation. According to Hansen and Mowen (2004), both profit and nonprofit entity could gain the benefit from planning and control that is provided by the budget. Before the budget is prepared, the organization should develop a strategic plan. The close relationship between the budget and the strategic plan helps management to ensure that all the attention is not focused on short-term operational. This is important because of the budget, as the plan period, has properties for short-term (Hansen and Mowen, 2004).

In a top-down budgeting system where plans and budget amounts have been set by the supervisor / subordinate power holders in order that the budget executors only do what has been set by the budget. The implementation of these systems results in performance of subordinates / executors of the budget to be ineffective because the target is too demanding, but the resources given insufficient (overloaded). Higher budget less know the potential and the barriers that are owned by a subordinate / budget executors as to provide a target which is very demanding in comparison with the ability of subordinates / implementing the budget. Therefore, the entity began to implement a budgeting system that can address the problem at the top of the system of participatory budgeting (participative budgeting). Through this system, subordinate / executors of the budget involved in the preparation of the budget concerning sub section in order to reach an agreement between the supervisor / subordinate power holders and the budget / budget execution of the budget (Omposunggu and Bawono, 2007).Many areas of accounting management research have looked at the problem of budget participation (Brownell, 1981). Many companies believe that the budget can improve performance. The creation of good performance can be realized if the manager can perform its functions properly. One of the tools to assess the performance is superior activity level budget participation of managers or employees. This is because the participatory budget assessed as having consequences on the attitudes and behavior of members of the organization (Murray, 1990). Effect of participatory budgeting on managerial performance is an interesting theme in accounting management research (Lukka, 1988). Brownell (1982b) mentions two reasons which are (a) participation that is considered as a managerial approach to improving the performance of members of the organization, and (b) the various studies that examine the relationship between participation and performance results are conflicting.

The Understanding of Budget

\section{Theoretical Study}

Both budget in public sector and business sector is a statement of what is expected, planned or expected to occur in a certain period in the future. The budget is not just a financial plan that charges a fee and 
revenue responsibility center within an organization but also a tool for top-level managers to control, coordinate, communicate, evaluate performance, and motivate subordinates (Kenis, 1979). Budget is a work plan that is expressed quantitatively and measured in monetary unit standard for translating the objectives and strategy of the company in operational units (Hansen and Mowen, 2004). Budget has two roles. First, it serves as planningin which the budget contains a summary of the organization's financial plan in the future. Second, it serves as the performance criteria such as the budget is used as a control system for measuring managerial performance. Budget is a very important thing in an organization.

Budget in the business sector according to Siegel et al., (1989) is the managerial planning of the activities expressed in the financial framework. Budget is also a comprehensive profit planning in a short term period which implements the goals and objectives into a company's operations. Furthermore, Hanson, (1966) stated that the budget is a formal statement made by the management of the plans that will be done in the future in a given period, which will be used as a guideline in the implementation of activities during the period. Therefore, the implementation of budget participation which is in not a right condition will damage the participation of employee motivation and decrease the effort to achieve corporate goals. Meanwhile, in the public sector, the state budget is a statement of the estimated expenditures and receipts that are expected to occur in a future period, as well as data on expenditures and the real income from the past. As said by Mardiasmo, (2002) budget is a financial plan to allocate financial resources through the political process to serve the needs of different communities. Country / area as a public sector entity also use the budget as a tool to achieve the goal. This is supported by Suparmoko (2000) who has argued that the budget is a list or a detailed statement of income and expenditure are expected within a specified period.Based on the above definitions, it can be concluded that the budget is a plan that is systematically arranged in the form of quantitative data and expressed in monetary units which covers all the needs of the company's activities for a certain period of time and is used as a management tool for planning, control and performance assessment in order to achieve organizational goals.

\section{Budget Participation}

Budget in both business sector and public sector are a statement of what is expected, planned or expected to occur in a certain periond in the future. The budget is not just a financial plan that charges a fee and revenue responsibility center within an organization but also a tool for top-level managers to control, coordinate, communicate, evaluate performance, and motivate subordinates (Kenis, 1979). Budget in the business sector and according to Siegel et al., (1989) it is the managerial planning of the activities expressed in the financial framework. Budget is also planning that has a comprehensive profit in the short term period that implements the goals and objectives into a company's operations. Furthermore Hanson, (1966) stated that the budget is a formal statement made by the management of the plans that will be done in the future in a given period which will be used as a guideline in the implementation of activities during the period. Therefore, the implementation of budget participation in a condition that is not right then it will damage the participation of employee motivation and decrease the effort to achieve corporate goals. Meanwhile, in the public sector, the state budget is a statement of the estimated expenditures and receipts that are expected to occur in a future period, as well as data on expenditures and receipts is really occur in the past (Mardiasmo, 2002). Supranto (2006) concluded that the budget process is a process of accounting and management processes. The accounting process for the preparation of the budget is the study of the mechanisms; procedures to assemble the data, and the format of the budget. Process management for budgeting is the process of defining the role of each head unit / work units in the implementation of programs or parts of programs and the establishment of centers of responsibility.

\section{Participation of Budgeting Plan}

Participation is a concept in which subordinates are involved in decision-making to a certain extent along with the boss in which the decision will have a future impact. Participation is basically an organizational process, where the individual involved and have influence in making decisions that have a direct influence on these individuals. In a broader sense, participation is at the core of the democratic process and therefore it is not natural if applied in an authoritarian organizational structure. In a more specific context, participation in budgeting is a process in which individuals, whose performance is evaluated and awarded, based on the achievement of budget targets, engage and influence in the preparation of the budget targets (Brownell \& McInnes, 1983).Becker and Green (1962) defined that participation is a decision-making process shared by two or more parties that will take effect in the future for the decision. The involvement of the leadership of an organization with regard to budgeting is a participation to determine the purpose of the organization. When applied in planning, participation means engaging the lower and middle-level leaders to draw up measures and make decisions regarding the purpose of the organization's operations. According to Argyris, (1952) the contribution of the budgetary process would occur if a subordinate involved to participate in the preparation of the budget. Therefore subordinate level of involvement in the budgeting process is the primary factor that 
distinguishes between the budget participatory and non-participatory budget (Milani, 1975). According to Bahr, (2002) the participation in the preparation of the budget allows the low leaders to negotiate with the leaders on the possibility of budget targets that can be achieved. Participatory budgeting is a process to make a decision shared by two or more parts of the organization and the decision to have an influence on the maker (French et al., 1990 in Siegel et al., 1989). Participation in the preparation of the budget also aims to shape the attitudes, behaviors of employees and managers and foster a motivational effect on the budget goals. Basically participation is a natural process in an organization, in which individuals were directly involved in making decisions that will affect him.

Several studies showed that the participation of more budget bring benefits for the organization. It is stated by Siegel et al., (1989) that the benefits of participation in the budgeting process are: (1) a person involved in the budgeting process that is not only the task but also ego involved in co-operation; (2) the person's involvement will increase the sense of community within the group, because it can improve collaboration between group members in setting goals, and can reduce distress; and (3) one's involvement will reduce the difference in the allocation of resources among units within the organization. However, in the budget there is limited participation. Siegers, (2004) suggested that the process of participation can provide the power, if they received support from the bottom of the leader and staff to be given the opportunity to determine or define the content of their budget, the opposite would be weak when they are not given the opportunity to determine and set the contents of the budget.

\section{Managerial Performance}

Managerial performance is one of the factors that can improve organizational effectiveness. Performance can be defined as the level to meet the expectations related to its functions. Managerial performance is a measure of how effective and efficient managers have been working to achieve organizational goals (Stoner, 1992). Managerial performance that has been obtained by the managers is a factor that can be used to enhance the effectiveness of the company. Managerial performance shows the ability of management to execute the functions of management is a business activity, which is of course always with regard to decisionmaking. As according to Williams (2001); David Kroenke (1989) stated that the management in carrying out the functions and activities of business include Planning, Organizing, Briefing, and Controlling that always need information to make decisions.Furthermore Mahoney, (1965) and Rudi (1998), Juniarti \& Evelyn (2003), suggested that the ability of management in terms of Planning, Organizing, Briefing, and Controlling may be an indicator of performance evaluation managerial, based on the view that performance management would be better if he has the ability to perform a function or activity of the business, which is influenced by the ability of quality information obtained from the information system of targeted and well integrated, in order to support management in the decision making process.

\section{The Relation of Budget Participation and Managerial Performance}

Becker and Green (1962) defined participation is a decision-making process shared by two or more parties that will take effect in the future for the decision. Argyris, (1952) found the greatest contribution of the budgetary process that would occur if a subordinate involved to participate in the preparation of budgets. Opinion was supported by Bahr, (2002) that the participation in the preparation of the budget provides an opportunity for leaders and staff down to negotiate with their employer about the possibility of budget targets that can be achieved and more realistic. It is based on the idea that when a goal or standard designed participatory is agreed, then lower leader and the staff will internalize goals or standards that as been set, and they also have a sense of personal responsibility to achieve it due to participation involved in the preparation (Milani 1975). According Hasen \& Moven (2004) budget is used for means of coordination, communication, performance evaluation and motivation, and includes an orientation and arrangement of employees in an organization or company. In a budgeting, it describes the process of role determination that deals with the responsible parties involved for carrying out the task of achieving the goals set in advance in the budget of an organization or a company. According to Brownell (1982), an organizational, managerial performance is closely related to participation in the preparation of the budget. Budgetary participation illustrates the involvement and influence of the managers in the budgeting process in an organization.

Research on the budget participation and performance has been done by placing the budgeting participation as independent variable and managerial performance as the dependent variable. The results showed that at the beginning of the study the relationship between budgetary participation and performance managers are often contradictory and inconclusive. Brownell and McInnes (1986) found that high participation in budgeting improve managerial performance. Frucot and White (2006) concluded that both the level of managerial and budgetary participation has a relationship (positive) direct managerial performance and job satisfaction. Yuen (2007) found evidence that participation budget is also shown to have a positive and significant impact on managerial performance. Mah'd et al, (2013) respondents who participated in the budget 
had significantly better performance indicators of the respondents who did not participate in the budget.The different results shown by Cherrington and Cherrington, (1973); Milani, (1975); Kenis, (1979); and Morse and Reimer, (1956) found that the budget participation has no significant effect on managerial performance. According to Mercant (1981), a negative relationship between participative budgeting and managerial performance can result from high levels of participation impact on the declining performance. This is caused by the influence of budgetary slack caused by the high participation in the budgeting. Budgetary slack which is disfunctional in the budgeting of this is the work done to organize the budget in hopes of achieving better performance.The big difference in the results of empirical studies occurs because the relationship of budget participation and managerial performance depends on situational factors, or better known as a contingency variable. Contingency approach systematically identifies various conditions or factors that may affect the relationship between budgeting participation with the performance of managers, so the relationship becomes strong and clear (Anthony and Govindarajan, 1998). Given this approach, the nature of the relationships exists in the budget participation with the performance of managers of different possibilities for each condition. The use of the contingency framework enables these factors act as moderating or intervening variables that will affect the relationship of budget participation with the manager's performance (Murray, 1990).

Contingency theory in the field of organization theory has contributed to the development of accounting management, especially in explaining the factors that influence the achievements of individuals and organizations. Sisaye, (1998) mentioned that the contingency theory is the design of control systems that are contingent on the contextual setting organization for the control system will operate. Implementation of the contingency approach in analyzing the control system, especially in the field of management accounting system has attracted the interest of researchers. The research literature describes the design of the system is usually used as a contingency factor that is moderating variables on performance. Contingency approach for the management accounting is based the premise that there is no universally management accounting system is always appropriate to be implemented across the entire organization in every circumstance, but the management accounting system also depends on situational factors. This theory identifies the forms of optimal control under operating conditions vary and describe how the operational control procedures. Brownell (1982) examined several studies and found the effect of conditional factors as moderating variable in the relationship between the independent variables and the dependent variable. The conditional factors can be grouped into four variables: culture, organizational, interpersonal, and individual.

\section{Conclusion}

Managerial performance that is obtained by managers is one of the factors that can be used to enhance the effectiveness of the company. Managerial performance shows the ability of management to execute the functions of management as a business activity which is of course always with regard to decision-making. The effectiveness of management's ability to carry out management functions are determined by the participation of a subordinate in budgeting plan. The biggest contribution of the budget process will occur if a subordinate involved participating in the preparation of the budget. Therefore, subordinate level of involvement in the budgeting process is the primary factor that distinguishes between the budget participatory and non-participatory budget. Results of empirical studies on the relationship of budget participation and managerial performance showed no difference. The big difference in the results of empirical studies occurs because the relationship of budget participation and managerial performance depends on situational factor or better known as contingency variable. The use of the contingency framework enables these factors act as moderating or intervening variables that will affect the relationship of budget participation with the performance of managers. The conditional factors can be grouped into four variables: culture, organizational, interpersonal, and individual.

\section{References}

[1]. Anthony, R. N. Vijay Govindarajan. 1998. Management Control Systems. Edisi 9. McGraw -Hill Companies, Inc. New York.

[2]. Argyris, 1952, The Impact of Budget on People. The controlership Foundation. Dalam Izzetin Kenis, 1979, Effect of Budgetary Goal Characteristic on Managerial Attitudes and Performance. The Accounting Review 4: 707- 720.

[3]. Becker, S. dan D. Green 1978. Budgeting and Employee Behavior, Journal of Business, October, hal. 392-402

[4]. Bahrul Elmi. 2002. Keuangan Pemerintah Daerah Otonomi di Indonesia, UI Press, Jakarta

[5]. Brownell, Peter. 1981. Participation in Budgeting, Locus of Control and Organizational Effectiveness. The Accounting Review, October, 844-860.

[6]. Brownell, Peter. 1982b. A Field Study Examination of Budgetary Participation and Locus of Control. The Accounting Review, October, 766-777

[7]. Brownell, P. dan M. McInnes. 1986. Budgetary Participation, Motivation, and Managerial Performance. The Acccounting Review. Vol. LXI(4). October: 587-600.

[8]. Cherrington, DJ. and JO. Cherrington, 1973. ìApproriate Reinforeement Contingencies in The Budgeting Processî. Journal of Accounting Research (Supplemen), pp. 225- 253

[9]. Frucot, Veronique andStephen White. 2006. Manajerial levels and the effects of budgetary participation manajers. Managerial Accounting, Vol. 61, No.4

[10]. Hansen dan Mowen. 2004. Cost Management : Accounting \& Control. United States: Thomson Southwestern

[11]. Hanson. E.I., 1966, The Budgetary Control Function, The Accounting Review, April. 239-243 
[12]. Juniarti dan Evelyne., 2003. Hubungan Karakteristik Informasi Yang Dihasilkan Oleh System Informasi Akuntansi Manajemen Terhadap Kinerja Manajerial Pada Perusahaan Manufaktur di Jawa Timur., Jurnal akuntansi dan keuangan., vol 5. No. 2, Nopember 2003 page 110-122.

[13]. Kenis, I. 1979. Effects of Budgetary Goal Characteristics on Managerial Attitudes, and Performance, Accounting Review, October, pp. $707-721$

[14]. Kroenke, David, 1989, Management Information System, Mc. Graww hill.

[15]. Lukka, K. 1988. Budgetary Biasing in Organization. Theoritica Fremework anf Empirical Evidence Accounting, Organization and Society 13. Pp. 281-301.

[16]. Mah'd, Osama., Al-Khadash, Husam., Idris, Mohammed., and Ramadan Abdulhahi. 2013. The Impact of Budgetary Participation on Managerial Performance: Evidence from Jordanian University Executives. Journal of Applied Finance \& Banking, Vol. 3, No. 3, p.133-156

[17]. Mahoney, T.A., T.H. Jerdee, and S.J. Carrol. 1965. The Job of Management. Industrial Relatians, pp. 9

[18]. Mardiasmo. 2002. Akuntansi Sektor Publik. Penerbit Andi. Yogyakarta

[19]. Merchant, D. 1981. The design of corporate budgeting system : influence on managerial behavior and performance. The Accounting review, 56, pp. 813-829.

[20]. Milani, K. 1975. The Relationship of Participation in Budget-Setting on Industrial Supervisor Performance and Attitudes: A Field Study. The Accounting Review 50. April. pp.104-123

[21]. Murray, Dennis. 1990. The Performance Effects of Participative Budgeting: An Integration of Interventing and Moderating Variables. Behavior Research In Accounting, Vol. 2, PP. 104-121.

[22]. Nazaruddin, Ietje. 1998. Pengaruh Desentralisasi dan Karakteristik Informasi Sistem Akuntansi Manajemen Terhadap Kinerja Manajerial. Jurnal Riset Akuntansi Indonesia Vol 1. N0 2. Hal 141-162.

[23]. Ompusunggu, Krisler Bornadi dan Bawono. Icuk Rangga. 2006. Pengaruh Partisipasi Anggaran dan Job Relevant Information (JRI) terhadap Asimetri Informasi. Simposium Nasional Akuntansi IX. Padan

[24]. Siegel and Marconi. 1989. Behavioral Accounting, Cincinnati, Ohio: South-Western Publishing Co.

[25]. Sisaye, Saleshi.1998. "An Overview of the Social and Behavioral Science Approaches in Mangement Control Research".Behavioral Research in Accounting. Vol. 10. pp.12-25.

[26]. Stoner, James A.F. 1995, Management, New Jersey, Prentice-Hall,Inc. Englewood Cliffs

[27]. Terry, George R. 1972. Principles of Management. Homewoods, Illinois: Richard D. Irwin, Inc.

[28]. William, S. M. 2001. Is Intellectual Capital Capital Performance and DisclosureRelated?. Journal of Intellectual Capital, 2 (3), 192203.

[29]. Yuen, Desmond. 2007. Antecedents of budgetary participation: enhancing employee's job performance. Manajerial Auditing Journal. Vol. 22 No. 5 